\title{
Estimation of nonadditive genetic impacts on lifetime performance through a grading-up breeding program with Holstein-Friesian
}

\author{
Zsolt Nemes ${ }^{1}$, Vitomir Vidović ${ }^{2}$, Dragomir Lukač², Ante Ivankovićc ${ }^{3}$ \\ Goran Grubicic , István Komlósi ${ }^{5}$, András Gáspárdy* \\ 'PIK "Bečej", Novosadska 2, 21220 Bečej, Serbia \\ ${ }^{2}$ University of Novi Sad, Faculty of Agriculture, Trg Dositeja Obradovića 8, 21000 Novi Sad, Serbia \\ ${ }^{3}$ University of Zagreb, Faculty of Agriculture, Svetošimunska 25, 10000 Zagreb, Croatia \\ ${ }^{4}$ University of Belgrade, Faculty of Agriculture, Nemanjina 6, 11080, Zemun, Serbia \\ ${ }^{5}$ University of Debrecen, Faculty of Agricultural and Food Sciences and Environmental Management, \\ Böszörményi 138, 4032 Debrecen, Hungary \\ ${ }^{6}$ Szent István University, Faculty of Veterinary Science, István 2, 1078 Budapest, Hungary \\ Received - Prispjelo: 22.08.2013. \\ Accepted - Prihvaćeno: 12.09.2014.
}

\begin{abstract}
The aim of this study was to estimate the total lifetime milk production and non additive genetic effects (recombination and heterosis) of cows with different proportions of Holstein-Friesian genes, obtained from the Serbian Fleckvieh (SF) and the Holstein-Friesian (HF) crossbreeding program in Vojvodina. Upgrading of local breeds with the Holstein-Friesian breed in Vojvodina started in 1971 and continued 2008. Six genotypes of cows $\left(F_{1}, R_{1}, R_{2}, R_{3}, R_{4}, R_{5}\right)$ were obtained with increasing percentage of Holstein genes, in order to attain purebred Holstein cows. Of all obtained genotypes, cows of genotype $\mathrm{R}_{4}$ with a proportion of Holstein genes from $96.87 \%$ had the highest lifetime milk production $\left(20000 \mathrm{~kg}\right.$ ), followed by cows $\mathrm{R}_{3}$ with $19950 \mathrm{~kg}\left(93.75 \% \mathrm{HF}\right.$ genes) and cows $\mathrm{R}_{5}$ with 19850 $\mathrm{kg}(98.44 \% \mathrm{HF}$ genes). Finally the process of upgrading resulted in pure Holsteins with $19780 \mathrm{~kg}$ of milk. The total lifetime production of milk fat did not show statistically significant difference $(\mathrm{P}>0.05)$ among the genotypes $R_{1}-R_{5}$ which ranged from 675 to $690 \mathrm{~kg}$. The pure Holstein obtained after sixth intermediate generations had the average lifetime milk fat production of $690 \mathrm{~kg}$. With the increase in the proportion of Holstein-Friesian genes percentage of milk fat was decreased, so that the cows of genotypes $\mathrm{R}_{3}, \mathrm{R}_{4}, \mathrm{R}_{5}$ and pure Holsteins, had less than $3.5 \%$ milk fat. In relation to the total milk yield, the highest realized heterosis effect was observed in the cows of $\mathrm{F}_{1}$ generation $\left(h_{F 1}^{R}=594 \mathrm{~kg}\right)$, while the lowest was observed in generation $\mathrm{R}_{2}\left(h_{R 2}^{R}=72 \mathrm{~kg}\right)$, where negative effect of recombination was also found $\left(r_{R 2}^{I}=-77 \mathrm{~kg}\right)$. Positive values of the actual and relative of heterosis effect of the milk fat yield was observed in all genotypes, whereas the negative heterosis effect of the milk fat percentage was observed also in all genotypes, with the exception of $R_{1}$ and $R_{2}$ cows, in which the typical consequence of the positive recombination in the early crossed Holstein-generations was manifested.
\end{abstract}

Key words: upgrading, heterosis, recombination, milk, cattle

\section{Introduction}

Production of beef and milk is increasingly becoming an important economic sector because of the greater interest and need for these products. Therefore the selection is aimed to create early maturing and productive animals. Since the middle of the nineteenth century to the middle of the twentieth century, the predominant genotype of cattle in Vojvodina was Serbian Fleckvieh Cattle. In the late sixties and early seventies, both in the world and in our 
country there has been an interest for the continental European breeds of cattle, such as Black-and-white Lowland Cattle, Danish Red and the Rotbunt cattle of Dutch origin and also the Jersey and Simmental (Fleckvieh) breeds. In the mid-seventies, serious shift in the development of dairy-type cattle in Vojvodina has occurred. But nowadays, we are witnessing that Holstein crosses are required for improvement of other local breeds (McAllister, 2002; Heins et al., 2006; Dechow et al., 2007; Swalve et al., 2008; Wall et al., 2003), and because of that reason there were exemplary initiatives in Serbia to improve the local Fleckvieh with Holstein-Friesian (Perišić, 2008). With organized importation of 660 high quality pregnant Holstein-Friesian heifers at PIK-Bečej and organized work on the genetic improvement of cattle in the population in Vojvodina was planned. There was an introduction of Blackand-white Holstein genes into the Serbian Fleckvieh breed with the aim being achieving $75 \%$ Holstein genetics. The program was implemented in practice, as in some European countries (Germany, Netherlands, France, etc.), by crossing the pure HolsteinFriesian breed into the existing breeds. As a result of specific work in an organized breeding program, maintaining the same number of cows, relatively satisfactory genetic and phenotypic progress was achieved. In addition there was a complete change achieved in genetic make-up in the requested type of cows with the minimal amount of Holstein-Friesian females being imported. A grading-up program includes a series of back crossing in order to transmit new or specific genes into a population from another gene pool in order to replace the genes of the original population with different genes to achieve better performances and more profitable farms. One of the aims of the crossing is to exploit a very mysterious phenomenon, the heterosis. The heterosis is an advantageous deviation of the $\mathrm{F}_{1}$ progeny performance from the theoretical parental mean. From the second progeny generation, the level of this advantage will be influenced by a recombination effect due to the new reassortment of the parental genes in the offspring.

The aim of this paper was to present a longstanding work on the improvement of Serbian Fleckvieh cattle with the Holstein-Friesian breed in the controlled environment of the farm.

\section{Material and methods}

Data for the upgrading program were obtained from two cattle farms in Vojvodina, which started in year 1971 and 1975 by crossing the Serbian Fleckvieh (SF) cows with bulls of the Holstein-Friesian (HF) breed imported from the USA and Canada. The whole process lasted until 2008, and six cow genotypes $\left(F_{1}, R_{1}, R_{2}, R_{3}, R_{4}, R_{5}\right)$ with different proportions of the Holstein genetics were obtained, in order to finally reach pure Holstein cows. Cows of $\mathrm{F}_{1}$ generation were created by mating SF cows to Holstein bulls, which had $50 \%$ Holstein genes. Each new generation was produced by consequent use of semen of Holstein-Friesian sires. The grading-up was conducted until we obtained a cow with HolsteinFriesian blood with a proportion of over $99 \%$. As a result of many years of crossing, cows of the following genotypes and proportion of Holstein genes was obtained: $\mathrm{R}_{1}$ with $75 \% \mathrm{HF}$ genes, $\mathrm{R}_{2}$ with $87.5 \% \mathrm{HF}$ genes, $\mathrm{R}_{3}$ with $93.75 \% \mathrm{HF}$ genes, $\mathrm{R}_{4}$ with $96.88 \% \mathrm{HF}$ genes, $\mathrm{R}_{5}$ with $98.44 \% \mathrm{HF}$ genes, in order to obtain the last generation of HF cows with $100 \%$ (>99 \%) proportion of HF genes.

After examining the system records of each cow, the proportion of Holstein genes in the overall genotype, the crossing levels and the number of generations, then the total lifetime quantity of milk and the amount and percentage of milk fat production was determined.

For the investigated traits the adjusted mean value (LSM - Least Square Means) was computed by the multiple trait hierarchical linear model and Duncan's post-hoc test for statistically significant differences among genotypes was applied (StatSoft, Inc., 2011). For the estimation of the nonadditive crossing effects the Dickerson-model (Dickerson, 1969) was applied. The realised heterosis $\left(h^{R}\right)$ is the deviation of the real performance from a theoretical value which is estimated as the sum of the results of the blood proportion $x$ the performance of the pure breeds being present at a given genotype (genetic composition: $\mathrm{p}_{\mathrm{si}} \mathrm{p}_{\mathrm{dj}}+\mathrm{p}_{\mathrm{di}} \mathrm{p}_{\mathrm{sj}}$ where, $\mathrm{p}_{\mathrm{si}}=$ Holstein-Friesian sire's gene proportion, $\mathrm{p}_{\mathrm{sj}}=$ Serbian Fleckvieh sire's gene proportion, $\mathrm{p}_{\mathrm{di}}=$ Holstein-Friesian dam's gene proportion, $\mathrm{p}_{\mathrm{dj}}=$ Serbian Fleckvieh dam's gene proportion). The relative heterosis $\left(h^{r}\right)$ represents, as a percentual value, the level of the previous realised heterosis. The additive component of the realised 
heterosis (defined as individual heterosis, $h^{I}$ ) has linear association with the degree of heterozygosity. It is made by the consecutive bisection from the heterosis appeared in the $\mathrm{F}_{1}$ genotype. The recombination $\left(r^{I}\right)$ is intended to characterize the distance of the realised heterosis from its additive component.

In the case of upgrading a breeding scheme there cannot be crossed sires with paternal heterosis. However, in the dairy production the crossbred stage of the dam contributes, as an environment, hardly to the individual performance. Therefore, the maternal heterosis is negligible. This is the reason that our investigation operates with the $h^{I}$ only like it was in the processing reported by Egger-Danner (2005).

\section{Results and discussion}

Table 1 shows the adjusted mean (LSM) and the adjusted standard mean errors $\left(\mathrm{SE}_{\mathrm{LSM}}\right)$ for the total lifetime milk production of cows with different genotypes. It can be seen that the purebred Serbian Fleckvieh (SF) cows produced 13,980 kg milk, while the improved cow generation $\mathrm{R}_{4}$ with a share in Holstein genes of $96.87 \%$ had the highest life milk production $(20,000 \mathrm{~kg})$, followed by genotype $\mathrm{R}_{3}$ with $19,950 \mathrm{~kg}$ (93.75 \% HF genes), then by the cows of genotype $\mathrm{R}_{5}$ with $19,850 \mathrm{~kg}(98.44 \%$ HF genes), and finally by the pure Holsteins (HF) gained 19,780 kg of milk.

Among the mentioned genotypes of the cows $\left(R_{4}, R_{3}\right.$ and $\left.R_{5}\right)$ there was no statistically significant difference $(\mathrm{P}>0.05)$ as compared to both purebreds (SF and HF) where a significant statistical difference $(\mathrm{P}<0.05)$ was observed. The largest heterosis $\left(h^{I}\right)$ and realized heterosis $\left(h^{R}\right)$ was recorded in cows of the $\mathrm{F}_{1}$ generation $(594 \mathrm{~kg})$, while the increase in the proportion of genes of Holstein-Friesian cattle led to the decrease of additive component of heterosis from generation to generation by $1 / 2$. The highest level of recombination $\left(r^{I}=464 \mathrm{~kg}\right)$ was recorded in cows with $\mathrm{R}_{3}$ genotype which contained the proportion of Holstein genes from $93.75 \%$, while the cows of genotype $R_{2}$ contained a proportion of $87.50 \%$ of HF genes had a negative recombination $(-77 \mathrm{~kg})$ and the least realized heterosis $\left(h^{R}\right)$ of 72 $\mathrm{kg}$. The smallest relative heterosis $\left(h^{r}\right)$ for lifetime milk yield - expressed as the percentual difference between the realized and expected production - appeared in the $\mathrm{R}_{2}$ genotype $(0.4 \%)$, while cows of $\mathrm{F}_{1}$ generation had the highest relative heterosis (3.5\%). Similar results have been published by other authors (Lopez-Villalobos et al., 2000; Sørensen et al., 2008; Freyer et al., 2008), in their research which had the aim to blend their local cattle breeds with purebred Holsteins.

In the research of Gáspárdy (1995) the average total lifetime milk production of the purebred Holstein-Friesians was $18,270 \mathrm{~kg}$ (with 1774 days long herd life, and with 2.12 lactations) in a Hungarian crossing process. Kräußlich (2002) published data about lifetime performance $(15,238 \mathrm{~kg}$ milk) of Simmental in Switzerland and he pointed out the superiority of the Simmental $\times$ Holstein crossed cows

Table 1. The lifetime milk production and non additive genetic effect in different cow genotypes

\begin{tabular}{cccccccc}
\hline Genotype & $\begin{array}{c}\text { Proportion } \\
\text { of Holstein- } \\
\text { gene, } \%\end{array}$ & $\begin{array}{c}\text { No. of } \\
\text { cows }\end{array}$ & $\begin{array}{c}\text { Total life time } \\
\text { milk yield, kg } \\
\text { LSM } \pm \mathrm{SE}_{\mathrm{LSM}}\end{array}$ & $\begin{array}{c}\text { Additive } \\
\text { component of } \\
\text { heterosis, } \\
\mathrm{kg}\left(h^{l}\right)\end{array}$ & $\begin{array}{c}\text { Recombination, } \\
\mathrm{kg}\left(r^{l}\right)\end{array}$ & $\begin{array}{c}\text { Realised } \\
\text { heterosis, } \\
\mathrm{kg}\left(h^{R}\right)\end{array}$ & $\begin{array}{c}\text { Relative } \\
\text { heterosis, } \\
\%\left(h^{r}\right)\end{array}$ \\
\hline $\mathrm{SF}$ & 0.00 & 277 & $13980^{\mathrm{a}} \pm 353$ & - & - & - & 0.0 \\
$\mathrm{~F}_{1}$ & 50.00 & 254 & $17470^{\mathrm{b}} \pm 354$ & 594 & - & 594 & $3.5^{* *}$ \\
$\mathrm{R}_{1}$ & 75.00 & 243 & $18860^{\mathrm{c}} \pm 347$ & 297 & 240 & 537 & $2.9^{* *}$ \\
$\mathrm{R}_{2}$ & 87.50 & 223 & $19120^{\mathrm{c}} \pm 332$ & 149 & -77 & 72 & 0.4 \\
$\mathrm{R}_{3}$ & 93.75 & 265 & $19950^{\mathrm{d}} \pm 308$ & 74 & 464 & 538 & $2.8^{* *}$ \\
$\mathrm{R}_{4}$ & 96.87 & 967 & $20000^{\mathrm{d}} \pm 199$ & 37 & 371 & 408 & $2.1^{*}$ \\
$\mathrm{R}_{5}$ & 98.45 & 2053 & $19850^{\mathrm{d}} \pm 175$ & 19 & 149 & 168 & 0.9 \\
$\mathrm{HF}$ & 100 & 6996 & $19780^{\mathrm{d}} \pm 143$ & - & - & - & - \\
\hline
\end{tabular}

abcd - different subscribed letters show significant differences $(\mathrm{P}<0.05)$

*,*, ** - number of subscribed stars show a significant difference from the Serbian Fleckvieh $\left({ }^{*} \mathrm{P}<0.05 ;{ }^{* *} \mathrm{P}<0.01 ;{ }^{* * *} \mathrm{P}<0.001\right)$ 
in the total amount of produced milk $(24,793 \mathrm{~kg}$ milk). This yield was between 20,140 and 24,491 kg reported for 59,7560 Holstein and holsteinized cows in Germany(Swalve, 2007). Whereas the average recorded value of lifetime performance of Holsteins in the Netherland was 30,543 kg of milk and 2,406 $\mathrm{kg}$ of milk fat and protein (Veepro Magazine, 2009). In their investigation Fürst and Sölkner (1994) come to a conclusion that in crossed populations the non additive genetic impacts result especially in an increase of milk yield.

The total lifetime fat production (Table 2) among the genotypes from $R_{1}$ to $R_{5}$ did not show statistically significant difference $(\mathrm{P}>0.05)$ which ranged from 675 to $690 \mathrm{~kg}$, while in comparison with the SF breed and $\mathrm{F}_{1}$ generation they showed statistically proven differences $(\mathrm{P}<0.05)$. The purebred Holsteins had an average life production of milk fat of $690 \mathrm{~kg}$, without a significant statistical difference $(\mathrm{P}>0.05)$ when compared to cows of genotype from $R_{1}$ to $R_{5}$. With the increase in the proportion of genes of the HolsteinFriesian, the additive component of heterosis $\left(h^{l}\right)$ was decreased. Positive values of the realised and relative heterosis effect on milk fat yield were observed in all genotypes. In cows of genotype $\mathrm{R}_{1}$, with proportion of $75 \%$ Holstein genes recorded the highest realised $\left(h^{R}=32.4 \mathrm{~kg}\right)$ and relative $\left(h^{r}=5.1 \%\right)$ heterosis, while the cows of the genotype $\mathrm{R}_{5}$ with the proportion of $98.45 \%$ Holstein genes had the least individual heterosis. Therefore the lowest realized heterosis, negative recombination, and relative heterosis was not able to be determined, which can be explained by the fact that it is already the sixth improved generation of cattle, where there is an advanced gene fixation and a reduced chance for recombination.

McAllister et al. (1994) recorded high relative heterosis in the total lifetime milk and milk fat production (from 16.5 to $20 \%$, respectively) in their work about the Holstein and Ayrshire crossing, while Van Raden and Sanders (2003) studied the length of a productive life in the different dairy crossed progenies sired by the Holstein and estimated heterosis which was low (1.2\%), which can be the result of the environmental factors (Bryant et al., 2007).

The Table 3 shows the milk fat content by the genotypes, where we observed that SF cows had the highest percentage of milk fat (3.68 \%). The milk fat percentage decreased with the process of gradingup, so that the cow genotypes $R_{3}, R_{4}, R_{5}$, and $H F$ had less than $3.5 \%$ milk fat. With the increase of the total lifetime milk production from generation to generation the milk fat content is decreasing, as it was expected based on knowledge from single lactation performances, given that these traits are in negative genetic correlation. Negative values of realised and expected heterosis effect on milk fat was observed in almost all genotypes, whereas the positive heterosis effect was only observed in the $\mathrm{R}_{1}$ and $\mathrm{R}_{2}$ genotype which is a typical consequence of the positive recombination in the early crossed generations.

Table 2. The lifetime milk fat production and non additive genetic effect in different cow genotypes

\begin{tabular}{cccccccc}
\hline Genotype & $\begin{array}{c}\text { Proportion } \\
\text { of Holstein- } \\
\text { gene, } \%\end{array}$ & $\begin{array}{c}\text { No. of } \\
\text { cows }\end{array}$ & $\begin{array}{c}\text { Total life time } \\
\text { milk fat yield, kg } \\
\text { LSM } \pm \mathrm{SE}_{\mathrm{LSM}}\end{array}$ & $\begin{array}{c}\text { Additive } \\
\text { component of } \\
\text { heterosis, } \\
\mathrm{kg}\left(h^{l}\right)\end{array}$ & $\begin{array}{c}\text { Recombination, } \\
\mathrm{kg}\left(r^{l}\right)\end{array}$ & $\begin{array}{c}\text { Realised } \\
\text { heterosis, } \\
\mathrm{kg}\left(h^{R}\right)\end{array}$ & $\begin{array}{c}\text { Relative } \\
\text { heterosis, } \\
\%\left(h^{r}\right)\end{array}$ \\
\hline $\mathrm{SF}$ & 0.00 & 277 & $514^{\mathrm{a}} \pm 11.4$ & - & - & - & 0.0 \\
$\mathrm{~F}_{1}$ & 50.00 & 254 & $617^{\mathrm{b}} \pm 11.4$ & 20.0 & - & 20.0 & $3.4^{* *}$ \\
$\mathrm{R}_{1}$ & 75.00 & 243 & $675^{\mathrm{c}} \pm 11.2$ & 10.0 & 22.4 & 32.4 & $5.1^{* * *}$ \\
$\mathrm{R}_{2}$ & 87.50 & 223 & $675^{\mathrm{c}} \pm 10.7$ & 5.0 & 8.5 & 13.5 & $2.1^{*}$ \\
$\mathrm{R}_{3}$ & 93.75 & 265 & $690^{\mathrm{c}} \pm 10.0$ & 2.5 & 11.3 & 13.8 & $2.1^{*}$ \\
$\mathrm{R}_{4}$ & 96.87 & 967 & $686^{\mathrm{c}} \pm 6.4$ & 1.3 & 3.4 & 4.6 & 0.7 \\
$\mathrm{R}_{5}$ & 98.45 & 2053 & $683^{\mathrm{c}} \pm 5.6$ & 0.6 & -0.5 & 0.1 & 0.0 \\
$\mathrm{HF}$ & 100 & 6996 & $690^{\mathrm{c}} \pm 4.6$ & - & - & - & - \\
\hline
\end{tabular}

abc - different subscribed letters show significant differences $(\mathrm{P}<0.05)$

${ }^{*, * *}, * * *$ number of subscribed stars sow a significant difference from the Serbian Fleckvieh $\left({ }^{*} \mathrm{P}<0.05 ;{ }^{* *} \mathrm{P}<0.01 ;{ }^{* * *} \mathrm{P}<0.001\right)$ 
Table 3. The lifetime milk fat percentage and non additive genetic effect in different cow genotypes

\begin{tabular}{cccccccc}
\hline Genotype & $\begin{array}{c}\text { Proportion } \\
\text { of Holstein- } \\
\text { gene, } \%\end{array}$ & $\begin{array}{c}\text { No. of } \\
\text { cows }\end{array}$ & $\begin{array}{c}\text { Lifetime average } \\
\text { milk fat content, } \% \\
\text { LSM } \pm \mathrm{SE}_{\mathrm{LSM}}\end{array}$ & $\begin{array}{c}\text { Additive } \\
\text { component of } \\
\text { heterosis, } \% \\
\left(h^{I}\right)\end{array}$ & $\begin{array}{c}\text { Recombination, } \\
\%\left(r^{I}\right)\end{array}$ & $\begin{array}{c}\text { Realised } \\
\text { heterosis, } \\
\%\left(h^{R}\right)\end{array}$ & $\begin{array}{c}\text { Relative } \\
\text { heterosis, } \\
\%\left(h^{r}\right)\end{array}$ \\
\hline $\mathrm{SF}$ & 0.00 & 277 & $3.68^{\mathrm{e}} \pm 0.020$ & - & - & - & 0.0 \\
$\mathrm{~F}_{1}$ & 50.00 & 254 & $3.53^{\mathrm{c}} \pm 0.020$ & -0.053 & - & -0.053 & $-1.48^{*}$ \\
$\mathrm{R}_{1}$ & 75.00 & 243 & $3.58^{\mathrm{d}} \pm 0.020$ & -0.027 & 0.073 & 0.046 & 1.30 \\
$\mathrm{R}_{2}$ & 87.50 & 223 & $3.55^{\mathrm{cd}} \pm 0.019$ & -0.013 & 0.051 & 0.038 & 1.08 \\
$\mathrm{R}_{3}$ & 93.75 & 265 & $3.46^{\mathrm{a}} \pm 0.018$ & -0.007 & -0.030 & -0.037 & -1.06 \\
$\mathrm{R}_{4}$ & 96.87 & 967 & $3.43^{\mathrm{a}} \pm 0.011$ & -0.004 & -0.059 & -0.063 & $-1.80^{*}$ \\
$\mathrm{R}_{5}$ & 98.45 & 2053 & $3.44^{\mathrm{a}} \pm 0.010$ & -0.002 & -0.046 & -0.048 & $-1.37^{*}$ \\
$\mathrm{HF}$ & 100 & 6996 & $3.49^{\mathrm{b}} \pm 0.008$ & - & - & - & - \\
\hline
\end{tabular}

abcde - different subscribed letters show significant differences $(\mathrm{P}<0.05)$

- number of subscribed stars show a significant difference from the Serbian Fleckvieh $\left({ }^{*} \mathrm{P}<0.05\right)$

Lopez-Villalobos et al. (2000) suggested that modern breeding methods, such as artificial insemination, embryo transfer, breeding programs such as TEAM or MOET, use sexed semen, reducing the number of bull lines leading to a reduction in genetic variability, resulting in an increase in the coefficient of inbreeding, while the rotational crossing of two or more breeds contributes to the manifestation of the effects of crossing and maintenance of genetic variability, which is important in maintaining the balance between production costs and future market requirements. When the crossed animals will be bred further (e.g. $F_{1} \times F_{1}$ mating, or grading-up is carried out), the breeders have to realise the loss in traits caused by non-additive genetic impacts, namely by recombination, which could contradict the valued heterosis that is expected. This genetic effect may sometimes be greater than the expected heterosis effect, although in each case the effect is to be expected in reverse. The success of the crossing requires a consistent and strict selection from the breeder.

Dickerson (1969) has shown that the maternal heterosis cancel out when the difference is taken between the crossbred and straight bred females mated to the sires of a different breed. Estimate of maternal heterosis in the beef production is applicable to any system of mating involving purebred bulls and either $F_{1}$ dams or crossbred females produced in terminal or rotational crossbreeding systems because its effects expressed in the calf are always present in approximately the same proportion to effects of in- dividual heterosis expected. Alternative designs employing $\mathrm{F}_{1}$ bulls may provide estimates of maternal heterosis without any effect of recombination but the results for reproduction are confounded with any effect of heterosis on the fertility of crossbred bulls.

\section{Conclusions}

With the use of crossing Serbian Fleckvieh cows with Holstein bulls, there is a possibility that after 38 years with a good working organization and breeding work, to get pure Holsteins after six generations. There was a simultaneous increase in the number of cows, and satisfactory genetic and phenotypic improvement was carried out as well as a total change in genetic composition. As result, we came to the desired type of Holstein-Friesian. With the increase in the proportion of Holstein-Friesian genes bred from generation to generation with optimal zootechnical requirements and care. There has been an increase in the total amount of milk, previously from $13,980 \mathrm{~kg}$ in SF to $19,780 \mathrm{~kg}$ in HF. However, the milk fat decreased from $3.68 \%$ to $3.49 \%$ but there has been an increase in the total milk fat yield from $514 \mathrm{~kg}$ to $690 \mathrm{~kg}$.

Research indicates that a planned crossing leads to the optimal gene recombination, which results in the increase in production and maintenance of the necessary variability for the purpose of continual positive success of selection on the observed properties. 


\section{Procjena neaditivnog genetskog učinka na životne performanse krava kroz "grading-up" uzgojni program $i$ korištenje holštajn-frizijske pasmine}

\section{Sažetak}

Cilj ovog istraživanja bio je prikazati procjenu ukupne životne proizvodnje mlijeka i neaditivan genetski učinak (rekombinacija i heterozis) krava s različitim udjelima gena holštajn-frizijske pasmine, dobivenih pretapanjem domaćeg šarenog goveda (SF) u holštajn-frizijsku pasminu goveda (HF) u Vojvodini. Pretapanje domaće pasmine $u$ holštajn-frizijsku pasminu obuhvatilo je razdoblje od 1971. do 2008. godine, a dobiveno je šest genotipova krava $\left(F_{1}, R_{1}\right.$, $\mathrm{R}_{2}, \mathrm{R}_{3}, \mathrm{R}_{4}, \mathrm{R}_{5}$ ) s različitim udjelom holštajn gena, do dobivanja krava holštajn pasmine. Od svih dobivenih genotipova, krave $\mathrm{R}_{4} \mathrm{~s}$ udjelom holštajn gena od 96,87 \% imale su najveću životnu proizvodnju mlijeka $(20.000 \mathrm{~kg})$, zatim slijede krave $\mathrm{R}_{3}$ sa $19.950 \mathrm{~kg}$ $\left(93,75 \%\right.$ HF gena) i krave $\mathrm{R}_{5}$ sa $19.850 \mathrm{~kg}(98,44 \%$ HF gena), da bi na kraju procesa pretapanja dobiveni čisti holštajn imao $19.780 \mathrm{~kg}$ mlijeka. U životnoj proizvodnji mliječne masti između dobivenih križanki $\left(\mathrm{R}_{1}-\mathrm{R}_{5}\right)$ nije utvrđena statistički značajna razlika $(\mathrm{P}>0.05)$ i kretala se od 675 do $690 \mathrm{~kg}$, dok je u usporedbi s roditeljskim čistim pasminama utvrđena statistički značajna razlika $(\mathrm{P}<0,05)$. Dobiveni čisti holštajn nakon šeste generacije u prosjeku imao je životnu proizvodnju mliječne masti od $690 \mathrm{~kg}$. S porastom udjela gena holštajn-frizijske pasmine, postotak mliječne masti je opadao, tako da su krave $R_{3}, R_{4}, R_{5}$, i čisti holštajn imale manje od 3,50 \% mliječne masti. U odnosu na ukupnu količinu mlijeka, najistaknutiji realizirani heterozis učinak zapažen je kod $F_{1}$ krava $\left(h_{F 1}^{R}=594 \mathrm{~kg}\right)$, dok je najniži zapažen kod $\mathrm{R}_{2}$ krava $\left(h_{R 2}^{R}=72 \mathrm{~kg}\right)$, kod kojih se pojavio negativan efekt rekombinacije $\left(r_{R 2}^{I}=-77 \mathrm{~kg}\right)$. Pozitivne vrijednosti ostvarenog i relativnog heterozis efekta na svojstvo prinosa mliječne masti uočene su u svim genotipovima, dok je negativan heterozis efekt za postotak mliječne masti, osim $u$ krava $R_{1} i R_{2}$, uočen u svim genotipovima krava, što je tipična posljedica utjecaja holštajn-frizijskog genotipa.

Ključne riječi: pretapanje pasmina, heterozis, rekombinacija, mlijeko, goveda

\section{References}

1. Bryant, J.R., Lopez-Villalobos, N., Pryce, J.E., Holmes, C.W., Johnson, D.L., Garrick, D.J. (2007): Effect of Environment on the Expression of Breed and Heterosis Effects for Production Traits. Journal of Dairy Science 90, 1548-1553. doi: dx.doi.org/10.3168/jds.S0022-0302(07)71640-5

2. Dechow, C.D., Rogers, G.W., Cooper, J.B., Phelps, M.I., Mosholder, A.L. (2007): Milk, Fat, Protein, Somatic Cell Score, and Days Open Among Holsteins, Brown Swiss and Their Crosses. Journal of Dairy Science 90, 3542-3549. doi: dx.doi.org/10.3168/jds.2006-889

3. Dickerson, G. (1969): Experimental approaches in utilizing breed resources. Animal Breeding 37,191-202

4. Egger-Danner, Ch. (2005): Analysis of Heterosis in Austrian cattle populations. In: Kreuzungszucht und Heterosis (ed. Ch. Fürst and Ch. Egger-Danner). Börsedruck GmbH., Wien, 11-17.

5. Freyer, G., Konig, S., Fischer, B., Bergfeld, U., Cassell, B.G. (2008): Crossbreeding in Dairy Cattle From a German Perspective of the Past and Today. Journal of Dairy Science 91, 3725-3743. doi: dx.doi.org/10.3168/jds.2008-1287

6. Gáspárdy, A. (1995): Influence of several factors on lifetime performance in dairy cows. Ph.D. Thesis. Gödöllő University of Agricultural Science, Gödöllo”.

7. Heins, B.J., Hansen, L.B., Seykora, A.J. (2006): Fertility and Survival of Pure Holsteins Versus Crossbreeds of Holstein with Normande, Montbeliarde, and Scandinavian Red. Journal of Dairy Science 89, 4944-4951. doi: dx.doi.org/10.3168/jds.S0022-0302(06)72545-0

8. Kräußlich, H. (2002): Future of the Fleckvieh breeding. Ideas about the breeding strategies. Fleckviehwelt 92, 4-8.

9. Lopez-Villalobos, N., Garricj, D.J., Blair, H.T., Holmes, C.W. (2000): Possible Effects of 25 Years of Selection and Crossbreeding on the Genetic Merit and Productivity of New Zealand Dairy Cattle. Journal of Dairy Science 83, 154-163. doi: dx.doi.org/10.3168/jds.S0022-0302(00)74866-1

10. McAllister, A.J., Lee, A.J., Batra, T.R., Lin, C.Y., Roy, G.L., Vesely, J.A., Wauthy, J.M., Winter, K.A. (1994): The Influence of Additive and Nonadditive Gene Action on Liefetime Yields and Profitability of Dairy Cattle. Journal of Dairy Science 77, 2400-2414. doi: dx.doi.org/10.3168/jds.S0022-0302(94)77183-6

11. McAllister, A.J. (2002): Is Crossbreeding the Answer to Questions of Dairy Breed Utilization? Journal of Dairy Science 85, 2352-2357. doi: dx.doi.org/10.3168/jds.S0022-0302(02)74315-4

12. Perišić, P. (2008): Reproductive and Productive Traits of Simmental Breed in dual-purpose Production and Cow-Calf System. Ph.D. Thesis, University of Belgrade, Belgrade-Zemun. 
13. Sørensen, M. K., Norberg, E., Pedersen, J. Christensen, L. G. (2008): Crossbreeding in Dairy Cattle: A Danish Perspective. Journal of Dairy Science 91, 4116-4128. doi: dx.doi.org/10.3168/jds.2008-1273

14. StatSoft, Inc. (2011). STATISTICA (data analysis software system), version 10. www.statsoft.com

15. Swalve, H. H. (2007): Tierzucht als Element einer zukunftsfähigen Landwirtschaft. 9. Jahrestagung Thüringer Landwirtschaft, Erfurt, 15. Februar

16. Van Raden, P. M., Sanders, A. H. (2003): Economic Merit of Crossbred and Purebred US Dairy Cattle. Journal of Dairy Science 86, 1036-1044. doi: dx.doi.org/10.3168/jds.S0022-0302(03)73687-X
17. Veepro Magazine (2009): Average milk production more than $30000 \mathrm{~kg} .73,6$.

18. Wall, E., Brotherstone, S., Kearney J. F., Woolliams, J. A., Coffey, M. P. (2003): Effect of including inbreeding, heterosis and recombination loss in prediction of breeding values for fertility traits. Interbull Bull. 31, 117-121. 